Article

\title{
Techs and the Cities: A New Economic Development Paradigm?
}

\author{
Gary Sands ${ }^{1}$, Pierre Filion ${ }^{2}$ and Laura A. Reese ${ }^{3, *}$ \\ ${ }^{1}$ Department of Urban Studies and Planning, Wayne State University, Detroit, MI 48202, USA; \\ E-Mail: gary.sands@wayne.edu \\ ${ }^{2}$ Faculty of Environment, University of Waterloo, Waterloo, N2L 3G1, Canada; E-Mail: pfilion@uwaterloo.ca \\ ${ }^{3}$ Urban and Regional Planning, Michigan State University, East Lansing, MI 48824, USA; E-Mail: reesela@msu.edu \\ * Corresponding author
}

Submitted: 6 March 2020 | Accepted: 16 June 2020 | Published: 29 September 2020

\begin{abstract}
Large technology firms pose new challenges for local economic development in the 21st century. They are attractive targets for local economic developers because they have the potential of providing permanent, well-paying jobs. This article examines two mega-economic development deals. Amazon's proposed second headquarters in Queens and Sidewalk Labs' Quayside proposal for the Toronto waterfront pit large and prosperous Big Tech firms against local governments with healthy economies. Amazon abandoned the New York City site it had chosen, rather than open new negotiations with local officials and citizens. Sidewalk Labs withdrew from the Quayside proposal after two and a half years of negotiation focusing mostly on the size of the proposed development. Although the potential benefits may be substantial, incentivizing Big Tech's location decisions may be well beyond the means of most cities, especially those with distressed economies.
\end{abstract}

\section{Keywords}

Amazon; Big Tech; local economic development; New York City; Sidewalk Labs; Toronto

\section{Issue}

This article is part of the issue "Planning for Local Economic Development: Research into Policymaking and Practice" edited by Godwin Arku (University of Western Ontario, Canada) and Evan Cleave (Ryerson University, Canada).

(C) 2020 by the authors; licensee Cogitatio (Lisbon, Portugal). This article is licensed under a Creative Commons Attribution 4.0 International License (CC BY).

\section{Introduction}

Over the past few decades, local economic development efforts, particularly in North America, have been affected by deindustrialization and the growth of information technology. The 'new economy' of the 21st century places greater emphasis on services and investments in human capital (Alcaly, 2003; Glaeser \& Saiz, 2004). Manufacturing employment in North America has declined as a result of both automation and the transfer of routine production activity to lower wage locations (Bluestone, 2003). The Computer Revolution has not only led to expansion of new highly skilled jobs, but it has also exacerbated the uneven growth of urban areas (Berger \& Frey, 2015).

The primary objective of this article is to assess how this ongoing economic restructuring has affected economic development practices in North America. We do this through an examination of two significant development proposals in which giant technology companies sought incentives and concessions from prosperous global cities. While development proposals at this scale are likely to be uncommon, we believe that these examples are indicative of how Big Tech may redefine the local economic development process.

For the past 75 years, governments have used incentives to redirect private investment to promote local economic development. Often, these efforts are justified as corrections for perceived 'market failures' (Seidman, 2005). Areas may be targeted because they are low income, with high unemployment and declining populations and property values. Incentives are perceived to be necessary to make these locations more competitive; private investments would not occur 'but for' the availability of incentives (Peters \& Fisher, 2004; Sands \& Reese, 2012). 
Critics of economic development incentives argue that they are a form of 'corporate welfare,' in effect paying firms to do what they would likely have done absent the incentives (LeRoy, 2005). Peters and Fisher (2004) suggest that $90 \%$ of economic development spending is wasted. When large scale investments are at stake, however, as in the location of a large manufacturing plant or corporate headquarters, the firms frequently have the upper hand in negotiations (LeRoy, 2018). Although they are often characterized as win-win situations, the public sector is typically responsible for substantial upfront costs, while the corporate investors receive benefits long before the government or its citizens do.

Traditional economic development strategies have sought to attract manufacturing jobs and the attendant investment in plant and equipment. In recent decades, globalization and deindustrialization have contributed to the decline of manufacturing, making competition for new manufacturing facilities more intense. The growth of information technology and the 'knowledge economy' has introduced a new focus for economic development activity (Berger \& Frey, 2015). Tech firms are desirable targets for economic developers because they pay high wages, are less restricted in their location choices by need for accessibility to raw materials, supply chains and customers, benefit from clustering of firms and contribute to a positive image for the host community.

The emergence of high-tech firms as a target of economic development efforts could fundamentally change the nature of local economic development. In this article, we consider several issues related to these potential changes: Does the focus on high tech firms represent a new local economic development paradigm, one that introduces new policy instruments, to attract high end jobs? Will this new focus also shift the balance of power between the public and private sectors, as well as among the communities seeking to attract new economy firms, those that are high tech and information intensive? How does this 'reaching for the top' in terms of firms and job categories and the economic status of residents differ from the previous economic development attempts to attract middle-class manufacturing jobs?

We offer two examples of urban economic development approaches that involve firms at the summit of the corporate hierarchy and that target, for the most part, high-income residents. One is the settlement of the headquarters of one of the largest US corporations and the other the planning and development by another giant firm of a central neighborhood according to a technologically driven model. While not claiming to cover all possible variants, these examples nonetheless illustrate how manifestations of this type of 'summit' development can differ from one another.

These examples share defining features of this topreaching form of urban economic development. First, they target highly valuable, centrally located land in global cities at the summit of their national urban system. Second, the main proponents are Tech Giants. The devel- opments target top corporations and, to a large extent, high-income residents. Although the attention in the article is on large projects deployed in global cities, analogous features of these projects are found in smaller-scale economic development initiatives occurring in variously sized urban areas. The focus is thus on iconic examples of an economic development transition that is widespread.

The next section of the article provides a brief overview of trends in local economic development policies. This is followed by a description of the cases, including a comparison of their key features. The article concludes with a discussion of the implications of these new economic development models for public policy.

\section{Economic Development Policy Trends}

Local economic development strategies have evolved through several phases during the last half of the 20th century (Eisinger, 1988; Jansa \& Gray, 2017; Tassonyi, 2005). From the mid-1980s, the emphasis was on the attraction or retention of businesses by providing subsidized infrastructure or targeted incentives such as tax abatements (Hill, Wolman, Kowalczky, \& St. Clair, 2012; Saiz \& Clarke, 2013). The second period introduced a new focus on financial, technological and knowledge infrastructure (Tassonyi, 2005). In the early 2000s, it appeared that the emphasis had begun to shift to strategies based on human capital development and quality of life enhancement including arts and culture-driven strategies (Florida, 2002; Grodach, 2011; Stern \& Seifert, 2010). These periods have been cumulative rather than evolutionary, however; once in place, early tools and strategies continue to be used. It appears difficult to 'wind down' the use of subsidies once they have been introduced (Jansa \& Gray, 2017).

The Great Recession (2008-2009) provided a flashpoint for revisiting local development policy to explore potential impacts on how local governments approach development and the extent of resources allocated to that effort. The stresses of the Great Recession appear to have reinforced the path dependency of local development policy, pushing municipalities toward ever more intensive use of the same old set of incentives. Businesses come to expect particular incentives once they are offered by a number of cities or states, and the tool becomes locked in place as a standard part of development packages (Reese, 2006; Sands \& Reese, 2012).

As manufacturing employment has decreased, local officials have become ever more focused on attracting higher order, often technology intensive employers. Research on cities that have managed to come back from economic distress has indicated that, while specific strategies have varied, investment in a technology-based economy and an 'environmentally friendly lifestyle' (read: a lifestyle for the upper and creative classes) has been common (Kodrzycki \& Muñoz, 2015). For a particular group of cities, those world class ones in the toptier, competition increases as they alone can afford the 
types of 'deals' that rent-seeking firms' desire in their location processes (Markusen \& Nesse, 2007). Although focused at the state level, some of the largest incentive deals in the US from 2006 to 2013 have gone to information technology firms and retailers that have substantial sales in e-tail such as Amazon and were provided by just "a few states subsidizing a few large firms" (Jansa \& Gray, 2017, p. 56).

Examinations of local development policy trends post-Great Recession have come to similar conclusions: "A dramatic rise in the use of business incentives" (Warner \& Zheng, 2013, p. 90) post-recession has led local officials to offer more and larger traditional incentives to attract new targets of employment, specifically the technology sector (Lowe, 2012). Analysis of the 2004 and 2009 International City/County Management Association surveys indicated that increasing numbers of local government respondents said that the technology sector was the primary focus of their economic development activities (Warner \& Zheng, 2013). Direct government financial support of research and development appears particularly important in attracting multinational firms (Rodríguez-Pose \& Wilkie, 2016) and the technology sector is increasingly the focus of local economic development (Warner \& Zheng, 2013). Similar conclusions have been drawn about economic development policy at the state level where overall spending on subsidies to influence industry location decisions has increased as has the number of very large subsidy packages, although again, states vary in the size of their incentives packages if not their content (Jansa \& Gray, 2017). In other words, the old dogs are being asked to perform the same tricks but for a different audience. But only a small group of cities can afford to have the largest dogs.

This is exacerbated by the fact that, along with the size of the incentive packages, the most sought-after businesses are increasingly those that provide high paying jobs for skilled workers. Research suggests that the largest firms and those most active in lobbying governments for incentives are likely to benefit the most from the increasing size of incentive packages (Jansa \& Gray, 2017) although there is a chicken and egg quandary here: Are incentive packages larger because of the changing nature of the firms that cities are trying to attract or do larger firms have the resources to drive the incentive packages upwards? From an equity standpoint, multinational firms appear to favor cities with greater connectivity in terms of producer services, airport passenger traffic and international co-inventor activity when locating their headquarters (Belderbos, Du, \& Goerzen, 2017), while high tech jobs are likely to locate in cities with a more advanced skills base (Berger \& Frey, 2015). These are also the communities most likely to be able to afford expensive incentive packages, leading to a rich get richer dynamic.

There are a variety of reasons-both political and economic - why public subsidization of private firms has increased over time in both numbers of incentives and the magnitudes of the deals: the recession, the path de- pendent nature of economic development policy, competition between cities and states, the loss of large manufacturing entities forcing communities to compete for a smaller pool of higher tech jobs, capture of the policymaking process by business via both lobbying and campaign donations, and the tendency for local officials to view subsidizing business as being in the 'public interest' (Bartik, 2019; Jansa \& Gray, 2017; Kwak, 2014; Posner, 2014; Sands \& Reese, 2012). At the same time, and despite considerable research attesting to their effectiveness, there has been a shift away from economic development incentives that invest in the local community more broadly defined: education, job training, services, and small business start-up support (Filion, Reese, \& Sands, 2019; Hill et al., 2012; Kodrzycki \& Muñoz, 2015; Reese \& Ye, 2011). Ten years after the end of the Great Recession and well into the global rise of high technology and Internet-dependent firms, has local economic development fundamentally changed?

\section{Case Study Methodology}

This article considers two examples of large economic development projects that made use of a variety of incentives to promote investment. The two case studies are based on a literature review and secondary analysis of publicly available documents, including government reports, corporate proposals, third party analyses and media reports. Details of the negotiations are not publicly available. As a result, we can be certain of outcomes but often not of the negotiations that led up to them.

In 2017, Amazon held an open competition to decide a location for its second headquarters (HQ2). The company announced its selection of Long Island City as one of two locations that would share the total investment and jobs, but then abandoned this location despite being offered a \$3 billion incentive package. Sidewalk Labs (the city-building division of Alphabet, the parent company of Google) responded to a request for proposals to create an innovation neighborhood in Toronto, but after two and a half years of plan making and negotiations, dropped the project invoking economic uncertainty caused by the COVID-19 pandemic. These highprofile cases were selected based on several criteria. First, we believe they reflect a turn in economic development tendencies, focusing on high-status jobs and residents, firms at the top of the corporate hierarchy and the most appealing cities and sectors therein. Second, they represent cases that illustrate bargaining between the public and private sectors. Finally, the local government agencies in New York and Toronto are expected to be in a relatively strong bargaining position vis a vis the high-tech firms at hand.

\subsection{Case Analysis: Amazon's HQ2}

Amazon exhibits many of the salient characteristics of the modern technology driven firm. In a relatively short 
period, it has risen from an on-line book retailer to become a diversified e-commerce conglomerate that is one of the most valuable companies in the world. The firm's profitability has been enhanced by some $\$ 2.4$ billion in subsidies that it has received from state and local governments over the years (Weise, Fernandez, \& Eligon, 2019). In initiating what has been described as a "Hunger Games-style civic competition" (Matsakis, 2018), Amazon's search for a location for a HQ2 epitomizes the superior bargaining power of Big Tech, as well as what can go wrong with economic development initiatives in the current post-manufacturing era.

The announcement by Amazon of an open competition to select the location for its HQ2 represents one of the single largest economic development opportunities in history. Amazon offered the winning city a $\$ 5$ billion investment and the creation of up to 50,000 well-paid new jobs (Matsakis, 2018). Implicit in the announcement was the expectation that Amazon would be able to obtain larger incentives through inter-municipal competition. In addition, the proposal responses (more than 200 in total) provided Amazon with valuable intelligence on the communities that were not selected.

Amazon's request for proposals identified the criteria that would be important in their decision. The company sought a site in an urban area with a minimum population of one million that offered readily available sites, affordable housing, good public transportation, and a large pool of skilled workers. Amazon essentially asked communities what such a massive investment and job creation opportunity was worth to them, what sort of tribute they were willing to offer to secure the favor of the world's richest individual.

There are a number of reasons why local communities would consider Amazon to be worthy of receiving incentives. As initially proposed, the Amazon HQ2 would provide a substantial number of jobs. The jobs would be new to the selected community and to the local labor market in general; that is, they would not be transfers from a nearby existing location. The new jobs would be highly desirable because they would be well paid, an average salary of $\$ 150,000$. These jobs are particularly attractive because they are 'new economy' jobs- digital, high-tech, information intensive-with good future prospects. Nor will they produce the negative externalities (such as air and water pollution) that a similar number of manufacturing jobs might. The Amazon HQ2 is perceived as being particularly footloose since it is not dependent on supply chains and distribution networks.

In November 2018, Amazon announced that it would split its HQ2 between New York City and Northern Virginia (Berube, 2018). Each location would see half of the total promised investment and half of the jobs. The New York site selected was Long Island City in Queens. The site is served by eight subway lines and the Long Island Railroad. Existing office space totals 2.5 million square feet, with 500,000 square feet available for phase one in the Court Square Building. In addition, Long Island City offered the potential for 7.6 million square feet of new construction, most on land controlled by the city and state (State of New York, 2017). Amazon's facilities would be integrated into the existing urban fabric, rather than being isolated on a separate campus; its space needs could be accommodated within a fiveminute walk.

The Long Island City neighborhood, while somewhat neglected, could hardly be classified as distressed. Indeed, the demographic profile of the ZIP code area that includes the site closely matches that of New York City as a whole (Table 1). Census Bureau data indicate that the area's recent job growth rate was double the Citywide average.

The incentive package that the City and State of New York offered to Amazon was valued at \$3 billion (Campbell, 2018). In return for creating 25,000 to 40,000 high paying jobs and occupying at least four million square feet of office space, Amazon's income taxes would be reduced by $\$ 2.1$ billion and its property taxes by $\$ 386$ million. An additional amount (up to $\$ 505$ million) would be in the form of cash grants tied to job creation.

On February 14, 2019, Amazon announced that it was canceling plans for its $\mathrm{HQ} 2$ investment in New York City (McCartney \& O'Connell, 2019). Amazon indicated that it was unwilling to proceed with the project in the face of grass roots and political opposition. Although there was a real risk that the project could be denied

Table 1. Socio-economic characteristics of the Long Island City area 2017 according to the American Community Survey (2017).

Population 2017

Average household size

$8,426,746$

Adults with BA

$36.7 \%$

$\$ 60,819$

Median household income

Poverty rate

$20.6 \%$

$4.2 \%$

$\$ 836,226$

Median home value
25,880

$47.0 \%$

$\$ 60,560$

$21.9 \%$

$6.7 \%$

$\$ 951,480$ 
a necessary approval by the Public Authorities Control Board (Ritholz, 2019), for the most part, the proposal enjoyed the support of the City and State (de Blasio, 2019; Goodman, 2019). A mutually acceptable agreement had been reached between Amazon and New York City and State, the details of which have not however been made public. When confronted with community and some political opposition, the firm simply decided to walk away.

\subsection{Case Study: Sidewalk Toronto's Quayside}

Toronto, Ontario is the fastest growing major urban region in North America. For Toronto, the issue is not how to attract economic development but rather how the seemingly inevitable growth can be managed most successfully. Thus, the effort by Waterfront Toronto to find a partner for the redevelopment of the Eastern Waterfront area should provide an example of an economic development scenario in which the public sector retains the upper hand.

The restructuring of Toronto's economy in the later decades of the 20th century has created opportunities for the redevelopment of the city's manufacturing and port facilities to accommodate the rapid growth of financial, technology and professional services employment, as well as recreation and tourism. Waterfront Toronto, a public body created by the Municipal, Provincial and Federal governments, was charged with overseeing the transformation of Toronto's lakeshore through infrastructure (including investments in flood control, wastewater management and transportation projects), open space development and participation in the creation of new employment and residential centers. Since its creation in 1999, Waterfront Toronto has been responsible for 2.5 million square feet of construction, 2,600 housing units and 90 acres of parks and public open space (Waterfront Toronto, 2017).

The Quayside site is located south of Lake Shore Boulevard East, about two kilometers east of Union Station (at the center of Downtown Toronto). To the south and east of the Quayside parcel, the area consists primarily of vacant industrial and commercial properties, most of which are in public ownership. North of the site, but separated from it by the elevated Gardiner
Expressway, is a residential area of mid-rise residential units. The demographic profile of the residential areas is similar to the city-wide statistics (Table 2).

In 2017, Waterfront Toronto issued a Request for Proposals for the redevelopment of Quayside, a 12-acre parcel on Toronto's eastern waterfront into a "globally significant demonstration project" (Waterfront Toronto, 2017, p. 9). Waterfront Toronto wanted more than just a builder: It sought "an innovation and financial partner" (Waterfront Toronto, 2017, p. 6). The Request for Proposals acknowledged that the agency lacked the inhouse expertise and financial capacity to accomplish all its objectives. It was also expected that this initial mixeduse neighborhood could set the stage for the remaining 700 acres of eastern waterfront.

The winning proposal was submitted by Sidewalk Labs, a Google affiliated company headquartered in New York City. Sidewalk's 200-page proposal (Sidewalk Toronto, 2018) called for the creation of a neighborhood that embraced technologies ('built from the Internet up') that would realize maximum benefits and efficiencies through constant monitoring of activities. Not only would modular buildings allow for their adaptation to changing circumstances over time, but quotidian adjustments could also be made to increase comfort and energy efficiency. The traffic patterns on streets could be adjusted in response to fluctuations in volume, direction and mode. The public realm was seen as a critical component of Quayside; for example, to encourage increased activity in the public spaces, the proposal called for inducing climate protection devices that would substantially increase the time when people would be comfortable outdoors.

Several aspects of the proposed Quayside neighborhood would set it apart from other developments. The high density, mixed-use characteristics of Quayside would make it vibrant and attractive. The buildings, some up to 30 stories tall, would be wood framed. Private vehicles would be discouraged in favor of walking, bicycling, public transit, and ride sharing services. This shift away from private vehicles would be fostered by an attractive public realm, priority pedestrian areas and bike lanes and climate adaptations. Quayside would also incorporate technological advances that, although not readily visible,

Table 2. Socio-economic characteristics of the Quayside area 2016 according to Statistics Canada (2016).

\begin{tabular}{lcc}
\hline & City of Toronto & \multicolumn{2}{c}{ Quayside Neighborhood } \\
& & CT 5350017.00 \\
\hline Population 2016 & $2,731,571$ & 7,906 \\
Average household size & 2.4 & 1.7 \\
Adults with BA & $36.4 \%$ & $49.8 \%$ \\
Median household income & $\$ 65,829$ & $\$ 63,104$ \\
Low income rate & $20.2 \%$ & $21.2 \%$ \\
Unemployment rate & $8.2 \%$ & $6.8 \%$ \\
Median home value & $\$ 601,922$ & $\$ 421,515$ \\
\hline
\end{tabular}


would be instrumental in achieving Waterfront Toronto's objectives with respect to realizing a climate positive development. An extensive digital network to collect, analyze and adjust these systems would be provided. Because of the experimental nature of the new technologies, one commentator described Quayside residents, workers, and visitors as "guinea pigs" (Sauter, 2018).

Sidewalk released a 1,500-page Master Innovation and Development Plan in June (Sidewalk Toronto, 2019). As proposed, Quayside would include some 2.65 million square feet of built space that would accommodate 3,952 workers and 2,670 residential units, along with retail, social infrastructure, and public spaces. The Master Innovation and Development Plan also outlined a plan for development of a second parcel, the nearby Villiers West neighborhood, proposed as the site of an innovation center that would include Google's Canadian headquarters and a new Urban Innovation Institute. Ultimately, Villiers West would include space for 7,680 jobs and 1,720 residences. Sidewalk Toronto would be the developer for these two neighborhoods (Sidewalk Toronto, 2019, Vol. 3, p. 87). The two areas would see a decrease in the total square footage built of about $7 \%$ from the initial Sidewalk proposal. Commercial development, however, would be increased by more than a million square feet, an increase of $150 \%$.

In addition to the Villiers West development, Sidewalk's Master Innovation and Development Plan outlined its vision for the redevelopment of an additional 155 acres to be known as the Innovative Design and Economic Acceleration District. The District would be a major initiative, accelerating job growth and investment. When fully developed, it would include almost 44,000 jobs and 30,470 dwelling units. Sidewalk Toronto would be the lead developer for the Advanced Systems that would extend throughout the Innovative Design and Economic Acceleration District-the power grid, thermal grid, waste management, stormwater management, freight management, dynamic streets, parking management, digital access and mobility systems (Sidewalk Toronto, 2019).

Sidewalk Labs argued that the inclusion of the entire Innovative Design and Economic Acceleration District was crucial to the success of the development of the first two neighborhoods. Many of the proposed innovative Advanced Systems are not economically viable at the scale of one or even two neighborhoods, but without them the Quayside proposal would not be as innovative and leading edge as either Sidewalk or Waterfront Toronto desires. Two among the Sidewalk justifications to proceed at the scale of the entire Eastern Waterfront, were the economies of scale required to support the development of a mass-timber production system, and the need to reap value added at this large scale to finance a Light Rail Transit (LRT), connecting the sector to Downtown Toronto. Consequently, Sidewalk was prepared to invest heavily in the development of the Innovative Design and Economic Acceleration District.
While Waterfront Toronto's Request for Proposals described Quayside as a pilot that could provide a model for the redevelopment of the entire Eastern Waterfront, the Sidewalk Labs' Master Innovation and Development Plan makes their participation in the subsequent development of the 155-acre Innovative Design and Economic Acceleration District essential. Sidewalk also requested 15 different regulatory adjustments and reforms, including pre-approval of flexible development regulations and innovative technology applications (Sidewalk Toronto, 2019, Vol. 3, pp. 224-226).

The Master Innovation and Development Plan proposed a financial partnership between Sidewalk and the public sector, primarily Waterfront Toronto and the City of Toronto (Sidewalk Toronto, 2019, Vol. 3). Sidewalk would invest $\$ 825$ million in the Innovative Design and Economic Acceleration district, plus $\$ 400$ million for optional credit support and $\$ 80$ million for an offsite tall timber factory (Sidewalk Toronto, 2019, Vol. 3, pp. 154-155). In return, Sidewalk Toronto would receive revenue from a variety of sources (Sidewalk Toronto, 2019, Vol. 3, pp. 174-179). For example, it would be exempted from certain development charges and fees. The company would also share in the increased land values and receive fees based on the costs of municipal infrastructure and advanced systems. Sidewalk Toronto would also earn fees for advisory services and for reaching performance targets. The amounts of these fees will be negotiated in the Implementation Agreement. If Sidewalk Toronto advanced funds for infrastructure construction, they would be repaid at market interest rates. Note as well that Sidewalk Labs stood to benefit financially from the devices it would invent for the Toronto waterfront development, as well as from the reputation of this project and the worldwide commissions that would ensue. Finally, Sidewalk Toronto sought performance fees to recoup some of the tax revenues generated by the developments it will catalyze.

The Sidewalk Labs proposal encountered a good deal of public opposition, considerably more than Amazon did in Long Island City. Some of the issues, such as concerns about guarantees of privacy (Kirkwood, 2019) and the requested waiver of public development regulations (Sauter, 2018; Sidewalk Toronto, 2018) are specific to Quayside. There was also a feeling among civic organizations and a newly elected provincial administration that the Master Innovation and Development Plan did not respect the original terms of the Waterfront Toronto Request for Proposals and as such constituted a 'land grab' (Benzie \& Rider, 2019). Other issues, such as complaints about inadequate public consultation and insufficient affordable housing opportunities (Bliss, 2019), are more general.

After several months of negotiation, Sidewalk Labs and Waterfront Toronto reached a tentative agreement on a list of critical threshold issues. The development was scaled back to the original 12-acre parcel, deferring decisions on the rest of the eastern waterfront until a later 
date. Sidewalk Labs, in partnership with a development company, would be responsible for the vertical development, while Waterfront Toronto would install the basic public infrastructure. Additional commitments of public resources would be negotiated separately. Many of the proposed innovations, such as district heating, waiver of development regulations and the creation of a data trust, were eliminated. In February 2020, Waterfront Toronto launched a consultation process on the revised proposals of Sidewalk, with the aim of arriving at a final decision on the development on 31 May 2020.

Even though the company had spent two and a half years and over 50 million dollars planning and promoting their proposal, on 7 May 2020, Sidewalk Labs announced that they were ending their involvement on the Toronto waterfront, citing the uncertainties resulting from the COVID-19 pandemic (Doctoroff, 2020; Passifiume, 2020). Different interpretations were advanced to make sense of the Sidewalk decision. There was, of course, a possible downward COVID-induced Toronto real estate trajectory. But the decision was taken at a time when it was still too early to fathom the long-term economic consequences of the pandemic (O'Kane, 2020). Another possible explanation was that Sidewalk never felt comfortable with the idea of limiting its Toronto waterfront presence to the 12-acre Quayside site. Finally, the view was advanced that Sidewalk was frustrated by the political dynamics of Toronto, involving the participation of local politicians and community groups in debates about the Toronto waterfront (Lorinc, 2020).

\section{Findings}

The review of these two economic development megadeals suggests that, despite important differences, they share important attributes. Both Amazon's New York HQ2 and Quayside were proposed for large and prosperous cities. Both projects were located on the fringe of their respective core business areas. Although both de- velopments are large scale, they would represent only a small part of the total growth in their respective areas.

Table 3 provides a summary of the key attributes of each of the projects. The types of incentives offered to the developers highlight the cumulative or path dependent nature of local economic development policies. Because Amazon withdrew from its development in Long Island City, less can be said about what the balance between the public sector's actual financial contribution and its returns might have been. Amazon asked each community to indicate what incentives they would be willing to give. New York City and State initially offered $\$ 3$ billion in incentives to secure a $\$ 5$ billion investment. Presumably, because Amazon would be splitting its investment and job creation between two locations, the value of the incentives would also decrease.

Bringing employment opportunities to the project location was an important component of both proposals. For Amazon, the development was all about jobs, well-paying, technical jobs. Access to a high-tech workforce appears to have been most decisive site selection criterion for Amazon. The New York and Washington metropolitan areas have the largest number of high tech (computer and mathematical occupations) workers in the country (Berube, 2018). The ready availability of existing sites and connectivity also seem to have been important factors.

The value of incentives, however, including grants, tax abatements and infrastructure investments, does not appear to have been a decisive factor in Amazon's decision. Locations close to the ones selected (Newark and Montgomery County) offered much larger incentive packages. As is often the case with economic development incentives (Sands \& Reese, 2012), the incentives were frosting on the cake. Sidewalk Labs sought less in terms of traditional incentives but rather asked for expedited development approvals and participation in project revenues that would normally accrue to the government entities. Rather than asking for large payments from lo-

Table 3. Summary comparison of projects.

\begin{tabular}{|c|c|c|c|c|}
\hline & Incentives sought & Nature of development & Who would benefit & Who would lose \\
\hline Amazon & $\begin{array}{l}\text { Land } \\
\text { Grants } \\
\text { Tax abatements } \\
\text { Infrastructure } \\
\text { investment }\end{array}$ & $\begin{array}{l}\text { Office headquarters } \\
\text { Highly paid jobs }\end{array}$ & $\begin{array}{l}\text { Amazon } \\
\text { Skilled, high tech } \\
\text { workers }\end{array}$ & $\begin{array}{l}\text { Lower income residents } \\
\text { Foregone city revenue } \\
\text { Reduced public capacity } \\
\text { for services }\end{array}$ \\
\hline Sidewalk & $\begin{array}{l}\text { Land } \\
\text { Revenue Capture } \\
\text { Regulatory flexibility } \\
\text { Development fee } \\
\text { exemptions } \\
\text { LRT }\end{array}$ & $\begin{array}{l}\text { Office headquarters } \\
\text { High density } \\
\text { Mixed use neighborhood } \\
\text { Technology test site } \\
\text { Smart infrastructure } \\
\text { Public spaces }\end{array}$ & $\begin{array}{l}\text { Sidewalk Toronto } \\
\text { Luxury residential } \\
\text { market } \\
\text { High tech workers }\end{array}$ & $\begin{array}{l}\text { Lower income residents } \\
\text { Foregone city revenue } \\
\text { Reduced public } \\
\text { capacity for services }\end{array}$ \\
\hline
\end{tabular}


cal governments, Sidewalk Labs offered to advance funds for the construction of the LRT connecting Quayside to Union Station.

The developers of these two projects also differed with respect to how they dealt with community reactions. Amazon's New York HQ2 encountered community opposition which Amazon cited as a reason for abandoning this location (Goodman, 2019). Amazon's approach to dealing with local governments in other locations strongly suggests that they were unlikely to make additional concessions to the community (Weise et al., 2019). The public opposition to the Sidewalk proposal was also substantial, but they continued to negotiate with Waterfront Toronto, eventually conceding a number of significant components of the proposals contained in their Master Innovation and Development Plan (Kirkwood, 2019; Zarum, 2019).

The projects discussed here involve high density developments serving largely high-end clienteles. As a result, the primary beneficiaries of both projects are skilled, educated, and better off residents, and of course, the bottom lines of the high-tech firms involved. Existing businesses, commercial and residential real estate interests are likely losers, as are middle and lower income residents who cannot afford the new housing or do not have the skills to benefit from the high tech jobs, and the general public that receives services from local governments with reduced revenues as a result of tax and fee diversion and the expenditures necessary to support the incentives. There is little evidence that the emphasis on high tech firms and clearer focus on higher income residents represents a new economic development paradigm. In our view, Big Tech has intensified the economic development incentive process, but has not fundamentally changed it.

\section{Conclusion}

We now return to the questions raised at the beginning of this article: First, does the focus on high tech firms represent a new local economic development paradigm, one that introduces new policy instruments to attract high end jobs? Communities continue to offer standard packages of incentives and abatements. Attempts to justify public investments in economic development are infrequent and often limited. For example, property tax abatements may be rationalized by projections of future income tax revenue, with little concern for indirect costs such as increased congestion and declining housing affordability. Amazon's original HQ2 proposal could be easily justified by the income tax revenue derived from an annual payroll of $\$ 750$ million. The Sidewalk Labs proposal did incorporate some innovative approaches to the structuring of public private partnerships, but these were not acceptable to Waterfront Toronto.

One aspect of local economic development that may be changing with the emerging emphasis on high tech and new economy investments is the shift from eco- nomic development focused on distressed and declining areas to the already prosperous areas where the Big Tech firms want to be anyway. It is not surprising that these examples are drawn from cities that are generally regarded as global and prosperous. While New York City and Toronto experience significant problems of high housing costs, congestion and strained public services, there is little indication that these issues have made them unattractive to private developers. If the thriving markets in these cities require billions of dollars of incentives to attract investments, what does this say about cities like Detroit, Cleveland, or Winnipeg? How much subsidy would be required to make these weak market cities attractive to large scale investments?

Second, will Big Tech shift the balance of power between the public and private sectors, as well as among the communities seeking to attract new economy firms, those that are high tech and information intensive? The decision to abandon each of these projects was made by the developer, rather than by the government. Indeed, local government officials expressed regret over the cancellation (de Blasio, 2019; "Sidewalk Labs has walked away," 2020). But these cases may not be indicative of a permanent or wide-spread paradigm shift. Amazon had invested little in the New York site and clearly had plenty of other available options. The decision to concentrate on the Northern Virginia location returned Amazon to their original HQ2 plan. While Sidewalk Labs invested heavily in the Quayside proposal, their objectives were much grander than Amazon's. Sidewalk Labs sought development control to well over a square mile of welllocated land in a prosperous community, participating in what are traditionally municipal revenue streams, access to detailed behavioral data and creating a test bed for technological innovations (that could be marketed to other cities). Such a proposal would likely be attractive to a community that was truly desperate, the sort of community unlikely to attract the interest of Big Tech.

Big Tech firms, such as Alphabet, are perhaps uniquely qualified to pursue these types of economic development strategies. Google has large cash resources that are readily available to be invested in projects such as the LRT. Obviously, it is easy for Sidewalk to obtain a commitment for the relocation of Google's offices to the District. Alphabet Companies are involved with development of autonomous vehicles and other technology applications that could be deployed in Quayside.

Third, how does this 'reaching for the top' in terms of firms and job categories and the economic status of residents differ from the previous economic development attempts to attract middle-class manufacturing jobs? It seems likely that the Big Tech firms will increasingly play a major role, seeking mega-deals that will support potentially transformative projects. Here we would include not only companies like Google and Amazon, but also advanced manufacturing firms which incorporate significant amounts of technology in their products, including motor vehicle and aerospace companies, computer 
chip manufacturers, battery and solar power companies. These firms will likely continue to expand, requiring large capital investments for which public subsidies and incentives will be sought. But not all communities can compete effectively in this arena. Cities and neighborhoods within them that are already attractive and prosperous will garner the lion's share of these new economic prizes.

An important consequence of these trends will be widening inequalities. Prosperous communities will attract the lion's share of investment and new jobs, both because they can offer richer incentive packages and because they are the locations the tech elite prefer. Struggling communities will fall further behind with some, out of desperation, continuing to offer incentive packages that they can ill afford. Big Tech firms will enjoy lower taxes with other taxpayers bearing the subsidy burden through higher taxes and reduced service levels.

Social equity objectives occupied a more important place among prior economic development policies than they do within the present emanation of such policies. They indeed attempted to attract investments to deprived areas and to create middle-class jobs, generally in the manufacturing sector. The middle-class nature of these jobs was in itself the main economic and social achievement of this form of economic development (LeRoy, 2005). The types of policies described here contrast with this earlier model of economic development. They are directed at the most economically appealing cities and urban sectors therein and create jobs for highly paid people and residential areas mostly dedicated to the rich, raising doubts about the distributive effects of these policies. Most open to criticism is the allocation of different forms of public sector support to the most profitable firms and to the highly paid employment and highincome residents attracted to these developments. If an argument can be made for the filtering down through the economy of the wealth generated by these developments, it is important to point out that most of the employment created by their multiplier effects is in lowwage service jobs. Furthermore, in the inflated housing markets of prosperous global cities, the arrival of such developments can cause a crowding out of mediumand low-income residents, thus exacerbating the consequences of income polarization. In short, the 'new' economic development paradigm fostered by the drive for high tech firms appears to lead to bigger deals with public support but without public input, using the same old incentives, by wealthy cities, to wealthy firms, for the benefit of wealthy residents.

\section{Conflict of Interests}

The authors declare no conflict of interests.

\section{References}

Alcaly, R. (2003). The new economy. New York, NY: Farrar, Strauss and Giroux.
American Community Survey. (2017). 2017 data release new and notable. US Census Bureau. https:// www.census.gov/programs-surveys/acs/news/datareleases/2017/release.html

Bartik, T. J. (2019). Making sense of incentives: Taming business incentives to promote prosperity. Kalamazoo, MI: W. E. Upjohn Institute for Employment Research.

Belderbos, R., Du, H. S., \& Goerzen, A. (2017). Global cities, connectivity, and the location choice of MNC regional headquarters. Journal of Management Studies, 54(8). https://doi.org/10.1111/joms.12290

Benzie, R., \& Rider, D. (2019, August 13). Sidewalk Labs a "terrible deal," Ford says: Premier questions public cost of company's desire to expand beyond original waterfront site. Toronto Star. Retrieved from https://www.pressreader.com/canada/ toronto-star/20190813/281509342821825

Berger, T., \& Frey, C. B. (2015). Did the Computer Revolution shift the fortunes of US cities? Technology shocks and the geography of new jobs. Regional Science and Urban Economics, 57, 38-45.

Berube, A. (2018). For Amazon, HQ2 decision was about talent, talent, talent. Brookings. Retrieved from https://www.brookings.edu/blog/the-avenue/ 2018/11/13/for-amazon-hq2-location-decisionwas-about-talent-talent-talent

Bliss, L. (2019, February 25). Critics vow to block Sidewalk Labs' controversial smart city in Toronto. CityLab. Retrieved from https://www.citylab.com/equity/ 2019/02/block-sidewalk-labs-quayside-torontosmart-city-resistance/583477

Bluestone, B. (2003). Beyond the ruins: The meanings of deindustrialization. Ithaca, NY: Cornell University Press.

Campbell, J. (2018). Amazon HQ2: \$3 billion in state, city tax breaks draws company to New York. Rochester Democrat and Chronicle. Retrieved from https://eu.democratandchronicle.com/story/news/ politics/albany/2018/11/13/new-york-amazonincentives-billion/1986979002

de Blasio, B. (2019, February 16). The path Amazon rejected. The New York Times. Retrieved from https://www.nytimes.com/2019/02/16/opinion/ amazon-new-york-bill-de-blasio.html

Doctoroff, D. (2020). Why we are no longer pursuing the Quayside project-and what's next for Sidewalk Labs. Medium. Retrieved from https://medium. com/sidewalk-talk/why-were-no-longer-pursuingthe-quayside-project-and-what-s-next-for-sidewalklabs-9a61de3fee3a

Eisinger, P. K. (1988). The rise of the entrepreneurial state. Madison, WI: University of Wisconsin Press.

Filion, P., Reese, L. A., \& Sands, G. (2019). Progressive economic development policies: A square PED in a round hole? Urban Affairs Quarterly. https://doi.org/ $10.1177 / 1078087419886362$

Florida, R. (2002). The rise of the creative class. New York, 
NY: Basic Books.

Glaeser, E. L., \& Saiz, A. (2004). The rise of the skilled city. Washington, DC: Brookings Institution Press.

Goodman, J. D. (2019, February 14). Amazon pulls out of planned New York City headquarters. New York Times. Retrieved from https://www.nytimes.com/ 2019/02/14/nyregion/amazon-hq2-queens.html

Grodach, C. (2011). Art spaces in community and economic development: Connections to neighborhoods, artists, and the cultural economy. Journal of Planning Education and Research, 31(1), 74-85.

Hill, E. W., Wolman, H. L., Kowalczky, K., \& St. Clair, T. (2012). Forces affecting city population growth or decline: The effects of interregional and intermunicipal competition. In A. Mallach (Ed.), Defining a future for American cities experiencing severe population loss (pp. 35-85). New York, NY: American Assembly.

Jansa, J. M., \& Gray, V. (2017). Captured development: Industry influence and state economic development subsidies in the Great recession era. Economic Development Quarterly, 31(1), 50-64.

Kirkwood, I. (2019, February 15). Leaked documents reveal Sidewalk Labs wants a lot more than Quayside. Betakit Canadian Startup News. Retrieved from https://betakit.com/leaked-documents-revealsidewalk-labs-wants-a-lot-more-than-quayside

Kodrzycki, Y. K., \& Muñoz, A. P. (2015). Economic distress and resurgence in U.S. central cities: Concepts, causes, and policy levers. Economic Development Quarterly, 29(2), 113-134.

Kwak, J. (2014). Cultural capture and the financial crisis. In D. Carpenter \& D. A. Moss (Eds.), Preventing regulatory capture: Special interest influence and how to limit it (pp. 71-98). New York, NY: Cambridge University Press.

LeRoy, G. (2005). The Great American jobs scam. San Francisco, CA: Berrett-Koehler Publishers.

LeRoy, G. (2018, November 16). The Amazon deal is even worse than it looks and will cost NY more than it thinks. Fast Company. Retrieved from https:// www.fastcompany.com/90269146/the-amazondeal-is-even-worse-than-it-looks-and-will-cost-nymore-than-it-thinks

Lorinc, J. (2020, May 7). Sidewalk Labs steps away from Toronto waterfront. Spacing. Retrieved from http://spacing.ca/toronto/2020/05/07/lorincsidewalk-steps-away-from-toronto-waterfront

Lowe, N. J. (2012). Beyond the deal: Using industrial recruitment as a strategic tool for manufacturing development. Economic Development Quarterly, 28(4), 287-299.

Markusen, A. R., \& Nesse, K. (2007). Institutional and political determinants of incentive competition. In A. Markusen (Ed.), Reining in the competition for capital (pp. 1-42). Kalamazoo, MI: W. E. Upjohn Institute for Employment Research.

Matsakis, L. (2018). Why Amazon's search for a second headquarters backfired. Wired. Retrieved from https://www.wired.com/story/amazon-hq2-searchbackfired

McCartney, R., \& O'Connell, J. (2019, February 14). Amazon drops plans to build headquarters in New York City. The Washington Post. Retrieved from https:/ www.washingtonpost.com/trafficandcommting/ amazon-drops-plan-to-build-headquarters-in-newyork-city/2019/02/14/b7457efa-3078-11e

O'Kane, J. (2020, May 24). Sidewalk's end: How the downfall of a Toronto 'smart city' plan began long before COVID-19. Toronto Globe and Mail. Retrieved from https://www.theglobeandmail.com/business/ article-sidewalks-end-how-the-downfall-of-atoronto-smart-city-plan-began

Passifiume, B. (2020, May 7). Sidewalk Labs pulling plug on Quayside project in Toronto. Toronto Sun. Retrieved from https://torontosun.com/news/ local-news/sidewalk-labs-pulling-plug-on-quaysideproject-in-toronto

Peters, A., \& Fisher, P. (2004). The failures of economic development incentives. Journal of the American Planning Association, 70, 27-37.

Posner, R. A. (2014). The concept of regulatory capture: A short, inglorious history. In D. Carpenter \& D. A. Moss (Eds.), Preventing regulatory capture: Special interest influence and how to limit it (pp. 49-56). New York, NY: Cambridge University Press.

Reese, L. A. (2006). Do we really need another typology? Cluster of local economic development strategies. Economic Development Quarterly, 20, 268-376.

Reese, L. A., \& Ye, M. (2011). Policy versus place luck: Achieving local economic prosperity. Economic Development Quarterly, 25(3), 221-236.

Ritholz, B. (2019). HQ2: Understanding what happened and why. Ritholz. Retrieved from https://ritholz.com/ 2019/hq2-understanding-what-happened-why

Rodríguez-Pose, A., \& Wilkie, C. (2016). Context and the role of policies to attract foreign R\&D in Europe. European Planning Studies, 24(11), 2014-2035.

Saiz, M., \& Clarke, S. E. (2013). Economic development and infrastructure policy. In V. Gray, R. L. Hanson, \& T. Kousser (Eds.), Politics in the American states: A comparative analysis (10th ed., pp. 501-532). Thousand Oaks, CA: CQ Press.

Sands, G., \& Reese, L. A. (2012). Money for nothing: Industrial tax abatements and economic development. Lanham, MD: Lexington Books.

Sauter, M. (2018, February 13). Google's Guinea-pig city. The Atlantic. Retrieved from https://www. theatlantic.com/technology/archive/2018/02/ googles-guinea-pig-city/552932

Seidman, K. F. (2005). Economic development finance. Thousand Oaks, CA: Sage Publications.

Sidewalk Labs has walked away: That's a lost opportunity for Toronto. (2020, May 7). Toronto Star. Retrieved from https://www.thestar.com/opinion/editorials/ 2020/05/07/sidewalk-labs-has-walked-away-thatsa-lost-opportunity-for-toronto.html 
Sidewalk Toronto. (2018). Vision sections of RFP submission. Toronto: Sidewalk Toronto. Retrieved from https://sidewalktoronto.ca/wp-content/uploads/ 2018/05/Sidewalk-Labs-Vision-Sections-of-RFPSubmission.pdf

Sidewalk Toronto. (2019). Master Innovation and Development Plan. Sidewalk Toronto. Retrieved from https://www.sidewalktoronto.ca/documents

State of New York. (2017). New York Metro Area Amazon HQ2 RFP response. New York, NY: State of New York. Retrieved from https://www.documentcloud.org/ documents/5513775-New-York-City-Amazon-HQ2Proposal.html

Statistics Canada. (2016). Census profile, 2016 census. Statistics Canada. Retrieved from https://www12. statcan.gc.ca/census-recensement/2016/dp-pd/ prof/index.cfm?Lang=E

Stern, M., \& Seifert, S. (2010). Cultural clusters: The implications of cultural assets agglomeration for neighborhood revitalization. Journal of Planning Education and Research, 29(3), 262-279.

Tassonyi, A. T. (2005). Local economic development: The- ory and the Ontario experience (ITP Paper 0511). Toronto: University of Toronto Rothman School of Management Institute for International Business.

Warner, M. E., \& Zheng, L. (2013). Business incentive adoption in the recession. Economic Development Quarterly, 12(2), 90-101.

Waterfront Toronto. (2017). Request for proposals innovation and funding partner for the Quayside development opportunity. Toronto: Sidewalk Toronto. Retrieved from https://sidewalktoronto.ca/ wp-content/uploads/2018/04/Waterfront-TorontoRFP-No.-2017-13.pdf

Weise, K., Fernandez, M., \& Eligon, J. (2019, March 3). Amazon's hard bargain extends far beyond New York. New York Times. Retrieved from https://www. nytimes.com/2019/03/03/technology/amazon-newyork-politics-jobs.html

Zarum, L. (2019, April 24). \#BlockSidewalk's war against Google in Canada. The Nation. Retrieved from https://www.thenation.com/article/googletoronto-sidewalk-gentrification

\section{About the Authors}
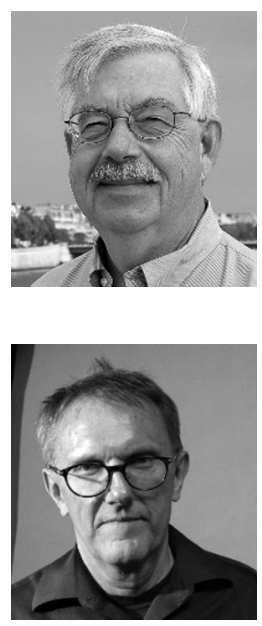

Pierre Filion is a Professor at the School of Planning of the University of Waterloo. His areas of research include metropolitan-scale planning, downtown areas and suburban centers, and infrastructures. He is Co-Editor of Critical Perspectives on Suburban Infrastructures (University of Toronto Press), Cities at Risk (Routledge) and five editions of Canadian Cities in Transition (Oxford University Press). He has published close to 200 articles and book chapters. He is presently co-editing a book on the impact of COVID-19 on urban planning and writing a book on planning downtown areas.

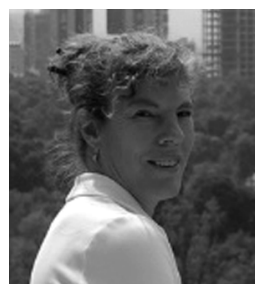

Laura A. Reese is Professor of Political Science and Urban and Regional Planning at Michigan State University. She is the Editor of the Global Urban Book Series for Ashgate/Routledge Publications and an Editor for the journal Animals. Her main research and teaching areas are in urban politics/studies and public policy, economic development, animal welfare policy, and local governance, management, and planning in Canada and the US. She has written 12 books and over 100 articles and book chapters in these areas. 